\title{
Biodiversity, ecosystem services and teaching: do our students understand how the functioning of ecosystems contributes to human well-being?
}

\author{
María Luisa Suárez Alonso and María Rosario Vidal-Abarca Gutiérrez* \\ Department of Ecology and Hydrology. Regional Campus of International Excellence "Campus Mare Nostrum"- \\ University of Murcia.Campus de Espinardo. 30100 Murcia. Spain.
}

* Corresponding author: charyvag@um.es

Received: 06/07/16 Accepted: 08/11/16

\begin{abstract}
Biodiversity, ecosystem services and teaching: do our students understand how the functioning of ecosystems contributes to human well-being?

The ecosystem services approach is being used by academics, researchers and managers to support and inform environmental management and biodiversity conservation. However, including this concept in training programs for university students is still poor or nonexistent. We analyzed student preferences in the degrees of Biology and Environmental Sciences at the University of Murcia (east Spain) of the ecosystem services delivered by two ecosystem types (aquatic and arid ecosystems). We specifically explored: What categories of ecosystem services (provisioning, regulating and cultural) is preferably selected by students in the two analyzed ecosystem types? Do students select different ecosystem services in each analyzed ecosystem?; Is this selection conditioned by gender?; Are students able to recognize the ecosystem services that arise from ecosystem functioning? A survey was completed by 264 students. It was designed to assess the perception of ecosystem services of two ecosystems in the Murcia Region: the Segura River and an arid landscape. Before completing the questionnaire, students were provided with a brief explanation about the concept and typology of the ecosystem services. Each student selected the five most important ecosystem services in each ecosystem of the 22 proposed. Provisioning services were preferentially selected by students for both ecosystems. Regulating arid ecosystem services, were selected by less than half the students. No significant differences were found in the selection of ecosystem services provided by the two ecosystems between males and females, although most regulating services provided by the arid ecosystem were preferentially selected by females. For the aquatic ecosystem, "freshwater" was selected as the main provisioning service. For the arid ecosystem, students preferentially selected "mineral raw materials" and all the regulating services were selected by less than $20 \%$ of students. A slight overlap was noted between the services selected by students and was proposed as being "very important" by ecosystem experts. We propose incorporating the framework of sustainability sciences as a platform to teach complex and interdisciplinary issues, the use of new pedagogical methods and the collaborative participation of university teachers.
\end{abstract}

Key words: Aquatic ecosystem, arid ecosystem, Degree of Biology and Environmental Sciences, gender, sustainability sciences.

\section{RESUMEN}

Biodiversidad, servicios de los ecosistemas y enseñanza: ¿Comprenden nuestros alumnos cómo el buen funcionamiento de los ecosistemas contribuye al bienestar humano?

La aproximación de los servicios de los ecosistemas está siendo utilizada por académicos, investigadores y gestores para contribuir a la gestión ambiental y a la conservación de la biodiversidad. Sin embargo, este concepto apenas está incluido en los programas de las asignaturas de Grado de las universidades. Este estudio analiza las preferencias de los alumnos de Grados de Biología y Ciencias Ambientales de la Universidad de Murcia, por los servicios ecosistémicos proporcionados por dos tipos de ecosistemas: acuático y árido. El trabajo explora, específicamente: qué categorías de servicios (abastecimiento, regulación y culturales) y qué tipo de servicios son seleccionados preferentemente en cada uno de los ecosistemas analizados; si esta selección está condicionada por el género y si los alumnos son capaces de reconocer los servicios que se derivan del funcionamiento de los ecosistemas. Se diseñó una encuesta a tal efecto para dos ecosistemas típicos de la Región de Murcia: el 
Río Segura y un paisaje árido, que fue completada por un total de 264 alumnos. Antes de rellenar la encuesta, a los alumnos se les proporcionó una breve explicación sobre el concepto y tipología de los servicios ecosistémicos. Cada alumno seleccionó los 5 servicios que consideró más importantes de los 22 propuestos. Para ambos ecosistemas, los alumnos seleccionaron preferentemente los servicios de abastecimiento, mientras que los de regulación y culturales fueron seleccionados por menos de la mitad de los alumnos. No se encontraron diferencias significativas en la selección de los servicios por razón de sexo, aunque la mayoría de los servicios de regulación del ecosistema árido fueron seleccionados preferentemente por las mujeres. Para el ecosistema acuático, el servicio de abastecimiento "agua" fue seleccionado preferentemente, mientras que para el ecosistema árido lo fue el de "materiales de origen geótico”. Para este ecosistema, todos los servicios de regulación fueron seleccionados por menos del $20 \%$ de los alumnos. Se encontró un escaso solapamiento entre los servicios seleccionados por los alumnos y los propuestos como "muy importantes" por los expertos en estos ecosistemas. Finalmente, proponemos la incorporación del marco de trabajo de las ciencias de la sostenibilidad como plataforma para la enseñanza de la complejidad de los ecosistemas y su gestión ambiental, el uso de nuevas técnicas pedagógicas y la participación colaborativa de los profesores de universidad en distintas disciplinas.

Palabras clave: Ecosistema acuático, ecosistema árido, Grados de Biología y Ciencias Ambientales, genero, ciencias de la sostenibilidad.

\section{INTRODUCTION}

One of the objectives of university education in the degrees of Biology and Environmental Science is to prepare future professionals to carry out the efficient management of ecosystems and natural areas. Today, human society faces complex environmental problems (e.g. global change, biodiversity loss, ocean acidification, climate change, etc.) (Liu et al., 2015) that require a multidisciplinary approach to understand and propose more adaptive measures than current ones that address sustainability.

Nowadays, the ecosystem services approach is used by academics, researchers, managers and policy-makers (e.g. Fisher et al., 2009; Lamarque et al., 2011) to support and inform about environmental management and biodiversity conservation strategies (Chan et al., 2006; 2011). In fact, international organizations (i.e. Millennium Ecosystem Assessment follow-up; TEEB; IPBES; the Convention of Biological Diversity's) and national organizations (i.e., the Millennium Ecosystem Assessment of Spain (SNEA, 2014) and Spanish Law 42/2007, on Natural Heritage and Biodiversity) have incorporated this concept to propose and design new environmental policy strategies.

The approach to ecosystem services derives from conceptualizing ecosystems and their bio- diversity as natural capital (MA, 2005), with ecological integrity and resilient able to generate a flow of services for human well-being by maintaining its functions (De Groot et al., 2002; Martín-López et al., 2009). These ecosystem functions involve the ecological processes that control the flows of material, energy, nutrients, and organic matter in ecosystems (Cardinale et al., 2012; Mace et al., 2012). Moreover, progress made in the ecosystem services science (López-Santiago et al., 2014) includes: the role of biodiversity for the supply of ecosystem services (Cardinale et al., 2012); the links between biodiversity, ecosystem functions and ecosystem services; the complexities that arise from such linkages (e.g. Balvanera et al., 2015); the identification of trade-offs, produced when the demand of one ecosystem service or many compromises other specific services (Raudsepp-Hearne et al., 2010); the targeting of ecosystem service associations to properly implement the concept into real conservation and management actions (Howe et al., 2014).

Many ecological processes and ecosystem functions are incorporated into the different disciplines of the degrees of Biology and Environmental Sciences, and we suspect that university students are unable to infer the complex relationships that link biodiversity, ecosystem functions, ecosystem services and human well-being. The 
"ecosystem services approach" framework could facilitate their understanding of the linkages among these components. Indeed, the ecosystem services concept has served as a pedagogical tool to provide an understanding of the relationships between human well-being and nature (Peterson et al., 2010).

Analyzing perceptions and preferences of different stakeholder groups in the ecosystem services delivered by different landscapes and ecosystems has been used to: detect potential conflicts and areas of mutual interest in ecosystems management (e.g. Agbenyega et al., 2009; Castro et al., 2011; 2015; Soy-Massoni et al., 2016); claim the role of the local population in landscape conservation (e.g. García-Llorente et al., 2012); design and propose a conservation management strategy (e.g.; Martín-López et al., 2012; López-Santiago et al., 2014).

Very few studies have used university students as a stakeholder group to analyze their preferences of the ecosystem services delivered by different ecosystems and their capacity to provide human well-being. However, the results of this research work could be useful to: 1) assess the adequacy of academic programs in environmental complexity; 2) adapt these teachings by incorporating emerging concepts such as social-ecological systems (e.g. Martín-López et al., 2013); and 3) incorporate new pedagogical

Table 1. Descriptive statistics of students' preferences toward ecosystem services provided by aquatic and arid ecosystems. (S.D. = standard deviation). Estadística descriptiva de las preferencias de los alumnos por los servicios ecosistémicos proporcionados por los ecosistemas acuático y árido (S.D. = desviación estándar).

\begin{tabular}{|c|c|c|c|c|c|c|}
\hline \multirow{2}{*}{ Ecosystem services } & \multicolumn{3}{|c|}{ Aquatic ecosystem } & \multicolumn{3}{|c|}{ Arid ecosystem } \\
\hline & $\mathrm{N}$ & Mean (\%) & S.D. & $\mathrm{N}$ & Mean $(\%)$ & S.D. \\
\hline \multicolumn{7}{|l|}{ Provisioning services } \\
\hline Food & 121 & 45.8 & 0.50 & 6 & 6.06 & 0.24 \\
\hline Freshwater & 200 & 75.8 & 0.43 & 2 & 0.76 & 0.09 \\
\hline Renewable energy & 40 & 15.2 & 0.36 & 110 & 41.7 & 0.49 \\
\hline Biological raw materials & 42 & 15.9 & 0.37 & 11 & 4.17 & 0.20 \\
\hline Mineral raw materials & 8 & 3.03 & 0.17 & 220 & 83.3 & 0.37 \\
\hline Genetic resources & 71 & 26.9 & 0.44 & 121 & 45.8 & 0.50 \\
\hline Natural medicines & 26 & 9.85 & 0.3 & 16 & 6.06 & 0.24 \\
\hline \multicolumn{7}{|l|}{ Regulating services } \\
\hline Climate regulation & 87 & 33.0 & 0.47 & 31 & 11.7 & 0.32 \\
\hline Regulation of air quality & 65 & 24.6 & 0.43 & 13 & 4.92 & 0.22 \\
\hline Water regulation and water quality regulation & 112 & 42.4 & 0.50 & 22 & 8.33 & 0.28 \\
\hline Erosion regulation & 30 & 11.4 & 0.32 & 43 & 16.3 & 0.37 \\
\hline Soil formation and fertility & 95 & 36.0 & 0.48 & 16 & 6.06 & 0.24 \\
\hline Natural hazard mitigation & 44 & 16.7 & 0.37 & 46 & 17.4 & 0.38 \\
\hline Biological control & 3 & 1.14 & 0.11 & 10 & 3.79 & 0.19 \\
\hline Pollination & 31 & 11.7 & 0.32 & 15 & 5.68 & 0.23 \\
\hline \multicolumn{7}{|l|}{ Cultural services } \\
\hline Scientific knowledge & 51 & 19.3 & 0.40 & 144 & 54.5 & 0.50 \\
\hline Local ecological knowledge & 52 & 19.7 & 0.40 & 132 & 50.0 & 0.50 \\
\hline Cultural identity and sense of belonging & 4 & 1.52 & 0.12 & 60 & 22.7 & 0.42 \\
\hline Spiritual and religious values & 11 & 4.17 & 0.20 & 15 & 5.68 & 0.23 \\
\hline Landscape-aesthetic values & 76 & 28.8 & 0.45 & 67 & 25.4 & 0.44 \\
\hline Recreation and ecotourism & 85 & 32.2 & 0.47 & 46 & 17.4 & 0.38 \\
\hline Environmental education & 63 & 23.9 & 0.43 & 151 & 57.2 & 0.50 \\
\hline
\end{tabular}


methods that help our understanding of the complex relationships between human and nature (e.g. Ban et al., 2015).

In this study, we analyzed the preferences of students who studied the degrees of Biology and Environmental Sciences at the University of Murcia of the ecosystem services delivered by two Spanish ecosystem types (aquatic ecosystem and arid ecosystem) and if this selection was due to training or gender reasons. We specifically explored the following questions: (1) What categories of ecosystem services (i.e. provisioning, regulating and cultural) were preferably selected by university students in the two analyzed ecosystems types?; (2) Did students select different ecosystem services in each analyzed ecosystem?; (3) Was this selection conditioned by gender?; and (4) Were students able to recognize the ecosystem services that arise from ecosystem functioning?

\section{METHODS}

The sampled population included to students who studied the degrees of Biology and Environmental Sciences at the University of Murcia (Spain). The study included three academic courses taught between 2012-2013 and 20142015. Students were asked to participate in the study and to respond individually to a questionnaire about the ecosystem services provided by two typical ecosystems in the Mediterranean Region. They were informed that all the responses would remain anonymous. The questionnaire was completed by 264 students. Sample size was similar to other surveys done on the perception of ecosystem services (e.g. Agbenyega et al., 2009: 84 respondents; García-Llorente et al., 2012: 381 respondents; López-Santiago et al., 2014: 314 respondents; Soy-Massoni et al., 2016: 241 respondents).

The questionnaire was designed to assess the perception of ecosystem services using original photographs of the two ecosystems which are the most characteristic of the study area; 1) an aquatic ecosystem: it corresponded to the Segura River, the main river that crosses the Murcia Re-
Table 2. Social characteristics and level of knowledge of the university students $(N=264)$. Características sociales y nivel de conocimiento de los alumnos $(\mathrm{N}=264)$.

\begin{tabular}{lc}
\hline Student profile & $N \quad \%$ \\
\hline Age & 19172.35 \\
$20-22$ years old & 5219.70 \\
$23-25$ years old & 217.96 \\
$>26$ years old & \\
\hline Degree & 15157.20 \\
Biology & 11342.80 \\
Environmental Sciences & 11844.70 \\
\hline Gender & 14655.30 \\
Male & 176.44 \\
Female & 24793.56 \\
\hline Environmental sensitivity & 17064.39 \\
Member of an NGO & 9435.61 \\
No member of an NGO & 3814.40 \\
\hline Knowledge about ecosystem services & 22685.60 \\
Known & \\
Not known & \\
\hline Knowledge about Millennium Ecosystem Assessment & \\
Known & \\
Not known & \\
\hline
\end{tabular}

gion; 2) an arid ecosystem: it corresponded to one of the arid landscapes in the Murcia Region. Two photographs, one of each ecosystem, were offered in a PowerPoint presentation (see Fig. S1, available at www.limnetica.net/es/limnetica/36) to the students.

Before completing the questionnaire, all the students were provided with a brief explanation about the concept and typology of ecosystem services and their benefits to society. Twenty-two ecosystem services (Table 1) were selected according to the classification provided by the Millennium Ecosystem Assessment (MA, 2005) and the Spanish National Ecosystem Assessment (SNEA, 2014). Seven services were classified as provisioning services, eight as regulating services and seven as cultural services (Table 1). Each student was asked to choose the five most important ecosystem services, at the most, from each analyzed ecosystem.

The questionnaire also included a set of questions about certain socio-demographic char- 
acteristics; e.g., age, gender, and environmental awareness/attitudes, e.g., members of environmental associations. Some questions asked them about their knowledge on "ecosystem services" and the "Millennium Ecosystem Assessment".

The qualitative information obtained from the questionnaires was coded $(1=$ selected service and $0=$ no selected service) to prepare a presence-absence matrix. Descriptive statistics (mean and standard deviations) and Wilcoxon rank-sum tests were performed to identify and describe the differences in the ecosystem services selected by the students among the three categories (provisioning, regulating and cultural services) (Objective 1), between aquatic and arid ecosystems (Objective 2) and between males and females (Objective 3). To test whether students could establish an ecosystem services-ecosystem functioning relationship (Objective 4), we compared the frequency of the services selected by the students with the relative importance (high, medium-high, medium-little, and little) of the ecosystem services for human well-being as established by experts in the UK (UK NEA, 2011), Spain (SNEA, 2014) and elsewhere in Europe (Harrison et al., 2010). However, this comparison should be interpreted with caution, since students have been forced to select only five of the twenty-two ecosystem services analyzed. This type of selection could underestimate some ecosystem services (e.g. cultural services). Hence the ecosystem services selected were considered "of high importance" for more than $76 \%$ of the students, as "medium-high" for $75-41 \%$ of them, as "medium-little" for $40-16 \%$ and as "of little importance" for less than $15 \%$ of the students.

\section{RESULTS}

\section{Characterization of students}

Most of the students $(72.35 \%)$ were aged between 20 and 22 years old. More than $57 \%$ of them (151) studied the degree of Biology and $42.8 \%$ (113 students) studied the degree of Environmental Sciences. Most were female (55.3\%).

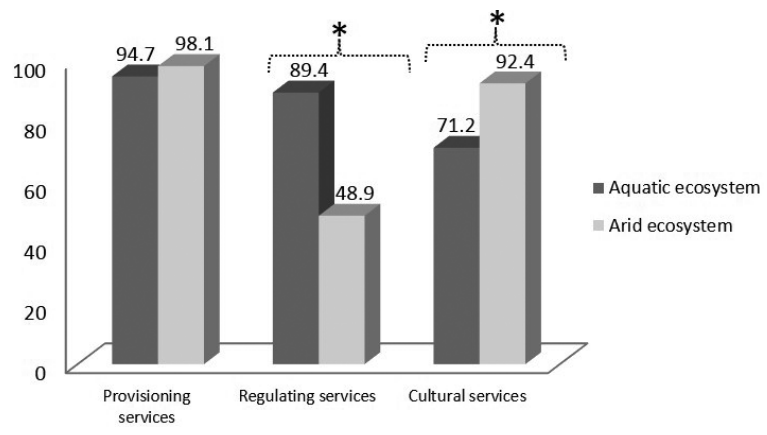

Figure 1. Histogram of the percentage of students selecting the different categories of ecosystem services for ecosystems analyzed. Asterisks show significant differences between both ecosystems using the Wilcoxon test $(p<0.0001)$. Histograma del porcentaje de alumnos que seleccionan las diferentes categorías de los servicios proporcionados por los ecosistemas analizados. Los asteriscos muestran las diferencias significativas entre ambos ecosistemas usando el test de Wilcoxon $(\mathrm{p}<0.0001)$.

Only 17 students are members of an NGO (Table 2). More than $64 \%$ of them acknowledged having heard of "ecosystem services", primarily from university teaching (146 students). More than $85 \%$ (226 students) did not know what exactly the Millennium Ecosystem Assessment was (Table 2).

\section{Preferences of ecosystem services in aquatic and arid ecosystems}

Provisioning services were preferentially selected by students for both ecosystems $(94.7 \%$ for the aquatic ecosystem and $98.1 \%$ for the arid ecosystem), as well as the cultural services provided by the arid ecosystem $(92.4 \%$ of students) (Fig. 1). The regulating services of the arid ecosystem were selected by less than half the students (48.9\%), although this percentage was much higher for aquatic ecosystems $(89.4 \%)$. Significant differences were found between the aquatic and the arid ecosystem for the regulating and cultural services (Wilcoxon tests; $p<0.0001$ for both; see Fig. 1).

No significant differences were found in their selection of the categories of ecosystem services provided by the aquatic ecosystem for both the Biology and Environmental Sciences students (Fig. 2a). Nevertheless, their selection of the re- 

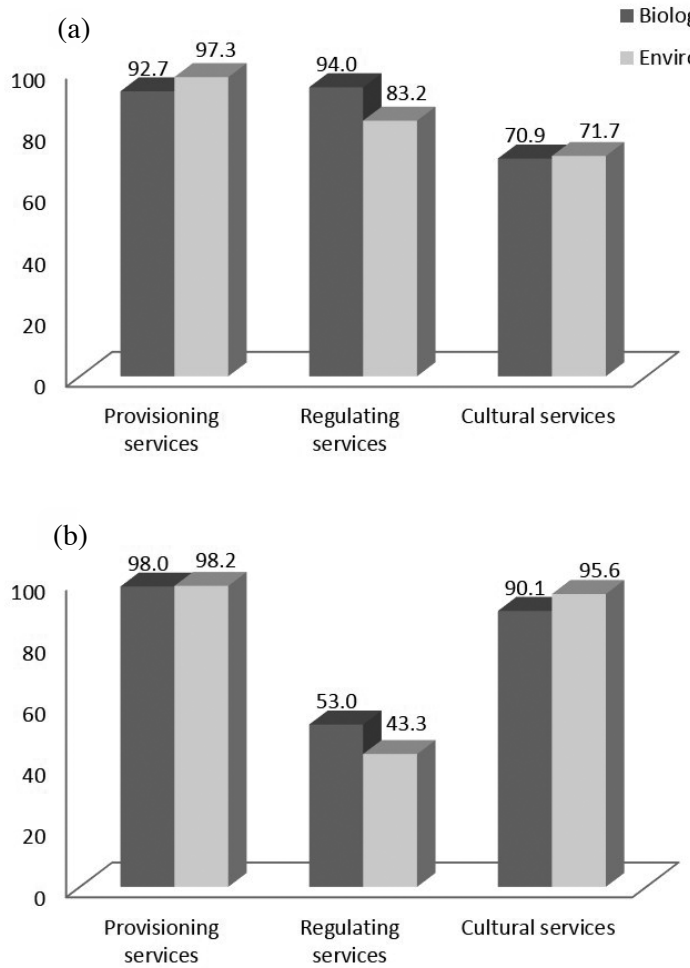

Figure 2. Histogram of the percentage of students of Biology and Environmental Sciences selecting the different categories of ecosystem services for aquatic (a) and arid (b) ecosystems. Histograma del porcentaje de alumnos de biología y Ciencias Ambientales que seleccionan las diferentes categorías de los servicios proporcionados por los ecosistemas acuático (a) y árido $(b)$.

gulating and cultural services for the arid ecosystem gave significantly differences between the Biology and Environmental Sciences students (Wilcoxon tests; $p<0.003$ for both; see Fig. 2b). Only $53 \%$ of the Biology students and $43.3 \%$ of the Environmental Sciences students selected the regulating services for the arid ecosystem (Fig. 2b).

No significant differences were observed between males and females in their selection of the ecosystem services provided by both ecosystems (Fig. 3), except for the regulating services of the arid ecosystem (Wilcoxon tests; $p<0.025$ ) (Fig. 3b).

For the aquatic ecosystem, "freshwater provision" was selected as the main provisioning service (75.8\% of the students), "water regulation and water quality regulation" $(42.42 \%)$ as the re-
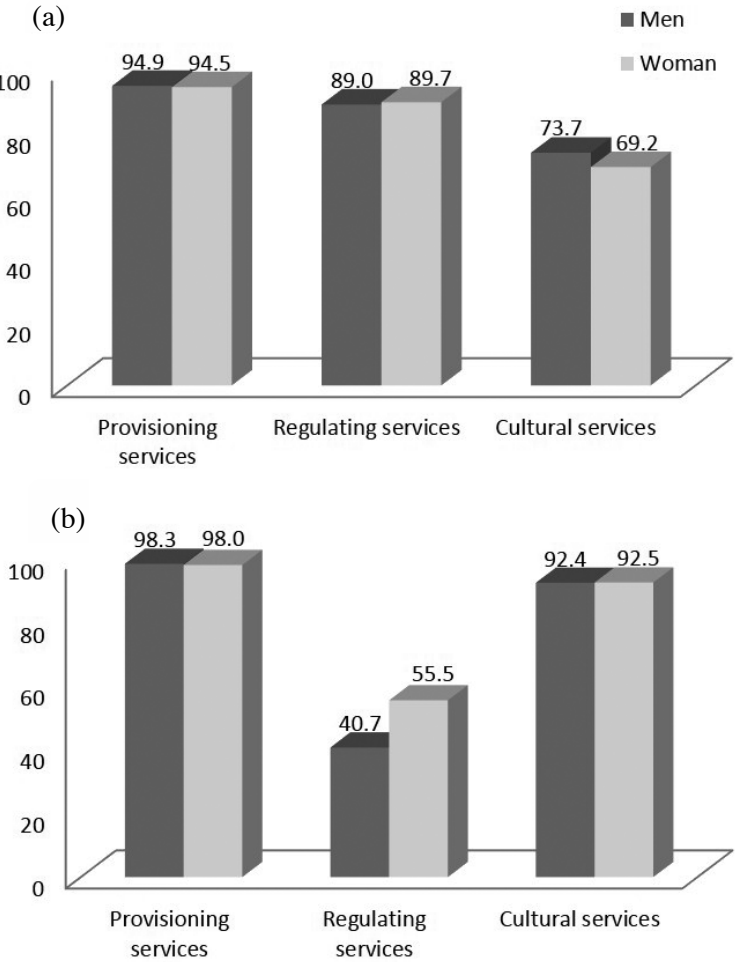

Figure 3. Histogram of the percentage of men and woman students selecting the different categories of ecosystem services for aquatic (a) and arid (b) ecosystems. Asterisk shows significant differences between both men and women using the Wilcoxon test $(p<0.025)$. Histograma del porcentaje de alumnos hombres y mujeres que seleccionan las diferentes categorías de los servicios proporcionados por los ecosistemas acuático (a) y árido (b). Los asteriscos muestran las diferencias significativas entre ambos ecosistemas usando el test de Wilcoxon $(\mathrm{p}<0.025)$.

gulating services and "recreation and ecotourism" as the main cultural service (32.2\%) (Table 1).

For the arid ecosystem, students preferentially selected "mineral raw materials" $(83.33 \%)$ as the main provisioning service, and "environmental education" (57.2\%) and "scientific knowledge" $(54.55 \%)$ as the major cultural services. All the regulating services provided by the arid ecosystem were selected by less than $20 \%$ of the students (Table 1). Among the regulating services, "erosion regulation" was significantly selected by females (Wilcoxon test; $p<0.003$ ), although "pollination", "natural hazard mitigation" and "regulation of air quality" were also preferentially selected by females (Fig. 4). Only the "wa- 


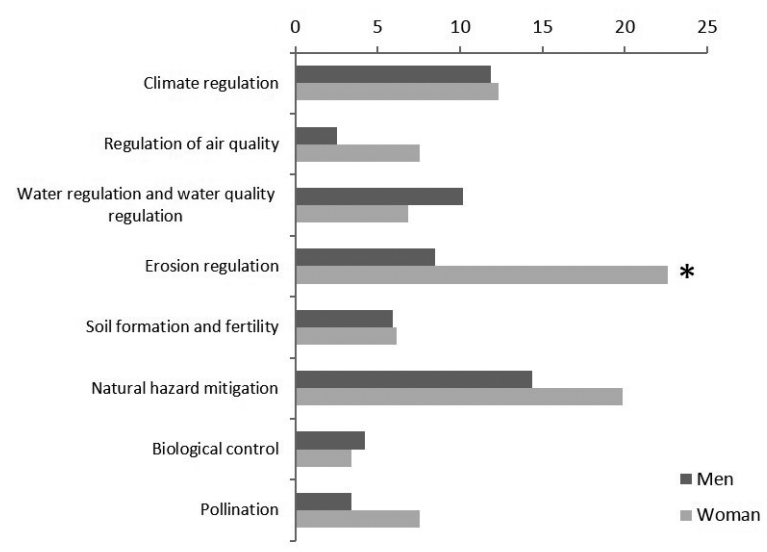

Figure 4. Percentage of men and women students selecting the single regulating services of arid ecosystem. Asterisk shows significant differences between both men and women using the Wilcoxon test $(p<0.003)$. Porcentaje de alumnos hombres y mujeres que seleccionan los tipos de servicios de regulación proporcionados por el ecosistema árido. Los asteriscos muestran las diferencias significativas entre hombres y mujeres usando el test de Wilcoxon ( $\mathrm{p}<0.003$ ).

ter regulation and water quality regulation" service was preferentially selected by males.

\section{Comparison between the opinion of experts and students on relative importance of ecosystem services in aquatic and arid ecosystems}

For the aquatic ecosystem, the students seem attached much less importance to all the single ecosystem services that attached by experts. Only the provisioning service "freshwater" coincided with the opinion of all the experts (Table 3) and "food" with experts from the UK. Among the regulating services, the little importance of "regulation of air quality" attached by students coincided with the experts from the UK, as did "pollination" with the expert from Spain. Students attached very little importance to all the cultural services (Table 3).

The relative importance of the ecosystem services delivered by the arid ecosystem attached by the students was compared with the opinion of Spanish experts as these ecosystems have not been assessed by experts from other countries (Table 3). In general, students attached very little importance to all the ecosystem ser- vices, especially regulating services (Table 3). Regarding provisioning services, both students and Spanish experts coincided by attaching little importance to "food" and "freshwater", but students better assessed "mineral raw materials". Finally, both students and experts coincided in attaching medium-high importance to cultural services "Scientific knowledge", "Local ecological knowledge" and "Environmental education", and in attaching little importance to "Spiritual and religious values" (Table 3 ).

\section{DISCUSSION}

In general, the students of the degrees of Biology and Environmental Science selected provisioning services rather than the regulating and cultural services according to other studies (e.g. Agbenyega et al., 2009; Hartter, 2010). This study also showed that students perceive regulating services as more important in aquatic ecosystems than in the arid ones. In contrast, cultural services are perceived as more important than regulating in arid landscapes. In fact, $48.9 \%$ of the students selected more than three cultural services of the arid ecosystem of the five they had to choose. These results contrasted with expert assessments (e.g. Quijas et al., 2012), which have highlighted that vegetation diversity is very important for the delivery of cultural services. Although many studies have shown the positive effect of vegetation on social preferences of cultural services, which explained why people prefer green landscapes to arid lands (e.g. DeLucio \& Múgica, 1994; García-Llorente et al., 2012; López-Santiago et al., 2014), the opposite response was found. Responses from people about their perception of the ecosystem services supplied by different ecosystems tended to be influenced by their origin, demands and world views (López-Santiago et al., 2014). In fact, most of the surveyed students come from Murcia and surrounding areas (Almeria and Alicante). In these three provinces, $62 \%$ of the arid lands of Spain are concentrated (Puigdefabregas, 2012). In this region, people have to face soil erosion, aridity, drought and flooding, which im- 
poses the way to manage natural resources and prints a special character on its inhabitants.

Among the cultural services provided by the arid ecosystem, "Environmental education", "Scientific knowledge" and "Local ecological knowledge" were the services perceived as being the most important, and were selected by more than half the students (Table 2). Martín-López et al. (2012) found that younger urban people's perception of ecosystem services is conditioned by formal education, and it was associated with a higher perception of "environmental education", which was also detected herein. The high percentage of students $(54.5 \%)$ who selected the cultural service of "scientific knowledge" could also be mediated by their higher level of education. However, our results did not agree with the relationship found by the above-cited authors between "Local ecological knowledge" and rural worldviews. Half the students selected this cultural service as being one of the most important ones (Table 2). This result is probably related

Table 3. Comparative table of relative importance allocated by experts to ecosystem services provided by aquatic and arid ecosystems in Europe (Harrison et al., 2010), the UK (UK NEA, 2011), Spain (SNEA, 2014) and students in this study. Tabla comparativa de la importancia relativa otorgada por los expertos a los servicios proporcionados por los ecosistemas acuático y árido en Europa (Harrison et al., 2010), Reino Unido (UK NEA, 2011), España (SNEA, 2014) y los alumnos en este estudio.

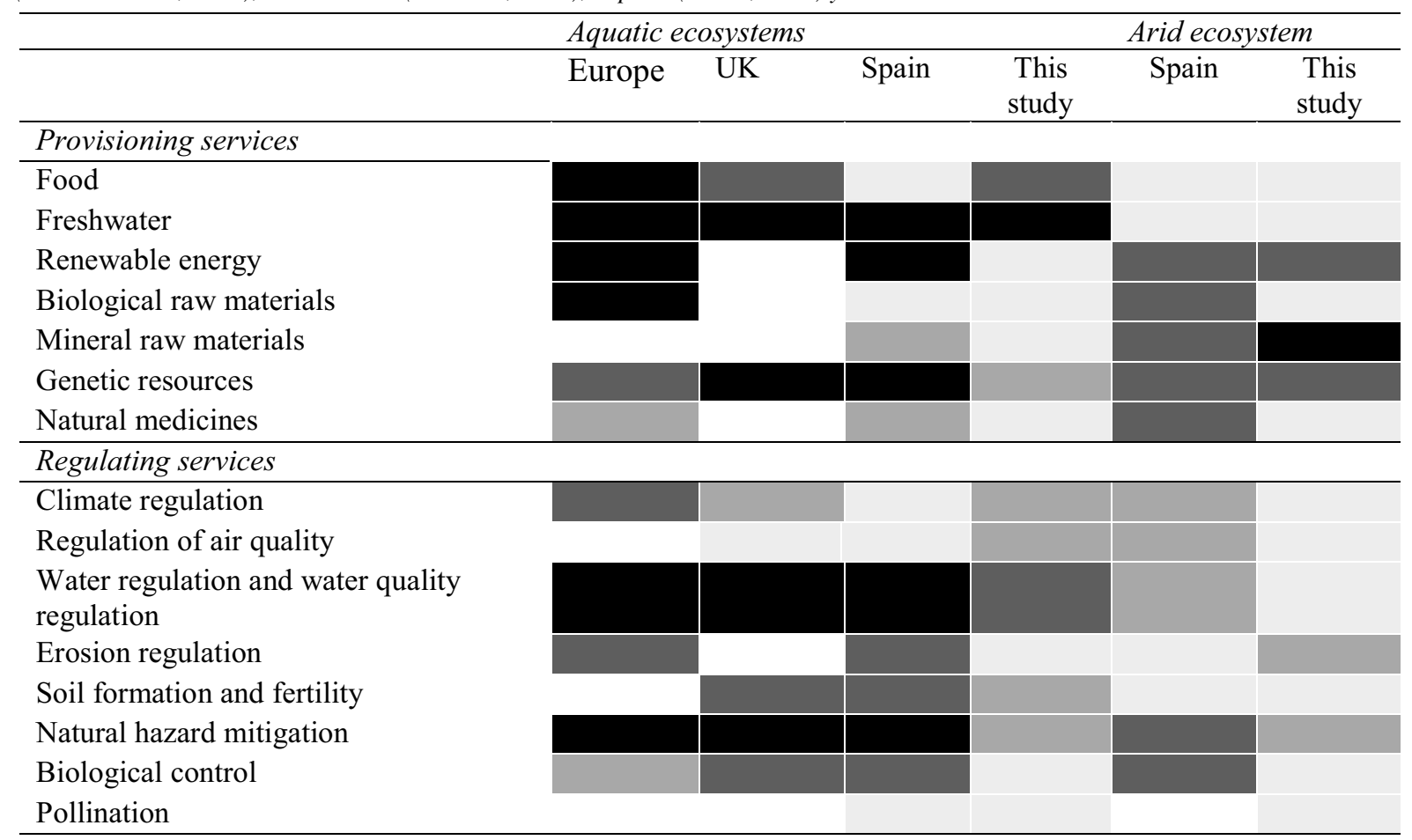

Cultural services

Scientific knowledge

Local ecological knowledge

Cultural identity and sense of belonging

Spiritual and religious values

Landscape-aesthetic values

Recreation and ecotourism

Environmental education
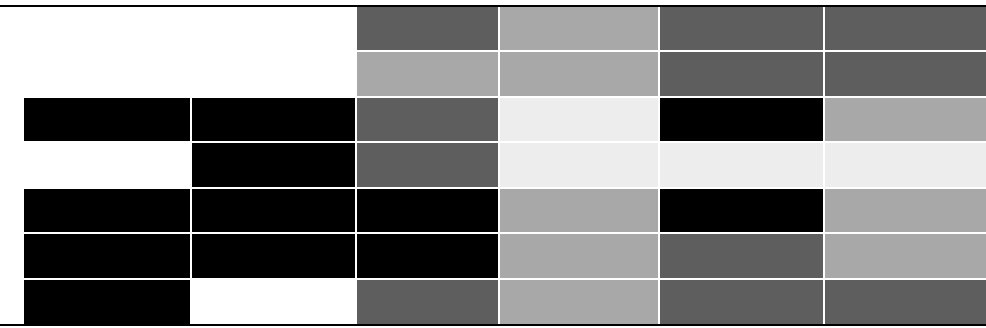
to the origin and history of the Murcian population. This aspect has been intensively studied by Pérez-Picazo (2006), who analyzed historical causes of rural features of today's society in Murcia.

Our results also showed that gender roles are important when university students selected ecosystem services. Females selected the regulating services in arid ecosystems more than males (Fig. 3b and 4), which is a similar finding to those obtained by other authors (e.g. Martin-López et al., 2012). On the contrary, no gender difference was seen when they selected of ecosystem services of the aquatic ecosystem. Very few studies have dealt with different preferences of ecosystem services between males and females (Iniesta-Arandia et al., 2014) to help explain these results. Nowadays, there is a demand to include gender perspective in ecosystem management policies (Kelemen et al., 2015) since women's perception of the natural world and use of natural resources differs from that of men (Iniesta-Arandia et al., 2014).

This study showed there is little agreement between the relative importance attached by students and experts to the ecosystem services delivered by both aquatic and arid ecosystems, and fundamentally for regulating services (Table 3). Only two regulating services for the aquatic ecosystem and none for the arid ecosystem that students classified agreed with the experts' assessment. However, these results should be analyzed with caution. Thus, for the arid ecosystem, experts also perceive regulating services as less important than the provision and cultural services (Table 3). For the aquatic ecosystem, the coincidence seems higher, although probably limited by the type of selection (Table 3 ).

According to Diaz et al. (2006), ecosystem services are benefits provided by ecosystems to humans, which contribute to make human life both possible and worth living. The capacity of ecosystems to provide eco-services depends on its ecosystem functions (De Groot et al., 2002), which involve the ecological processes that control the fluxes of energy, nutrients and organic matter in an ecosystem (Cardinale et al., 2012). For instance, decomposition is the ecological process by which different organisms are capable of breaking and recycling dead organic material (i.e. ecosystem function), and it is able to directly provide the ecosystem service clean water ("water quality regulation"). Similarly, primary production is the ecological process by which plants use sunlight, water, and organic and inorganic elements to produce biomass (i.e., ecosystem function), which directly provide with the ecosystem services of food and timber, or fiber ("biological raw materials"). The low relationship found between the assessments made by students and experts of the relative importance of the ecosystem services provided by both ecosystems suggested that university training does not qualify students sufficiently to perceive the complex relationships that link biodiversity, functions, ecological processes and the functioning of ecosystems. For instance, after observing the photograph of the aquatic ecosystem, students were unable to evaluate how "very important" the two regulating services inherent in this ecosystem were: "water regulation and water quality regulation" and "natural hazard mitigation".

In general, the academic programs in the degrees of Biology and Environmental Sciences include all the basic biophysical processes that support life on Earth. However, the current dominant educational model is based on single discipline-oriented learning, which does not help in the important, yet challenging, task of teaching complex environmental issues, and even less so with the benefits that healthy ecosystems provide society with (Castro et al., 2011). As pointed out by Ban et al. (2015), the emerging discipline of sustainability sciences (e.g. Clark \& Dickson, 2003; Chapin et al., 2010; Martín-López et al., 2013), based on social-ecological systems (Ostrom, 2009), could serve as a platform for the teaching of complex and interdisciplinary issues. Garcia-Llorente et al. (2015) have demonstrated that ecosystem services are coproduced by both ecosystems and social systems; i.e. by biophysical and socio-cultural factors (Díaz et al., 2011). Consequently, the management of ecosystems and natural resources toward sustainability should recognize the complexity and non lin- 
earity of nature-society relations (Martín-López et al., 2013), which are nowadays ignored in university teaching.

Many pedagogical methods exist to engage in teaching complex environmental issues, including experiential learning; transformative social learning, games and problem-based learning (see the review of Ban et al., 2015). To develop these methods, the collaborative participation of teachers from different disciplines is essential, and this is a challenge for the current university community.

\section{ACKNOWLEDGEMENTS}

We wish to thank the university students who participated in this study. Special thanks go to Helen Warburton for helping with the English. This work is dedicated to the memory of Maria Rieradevall (1960-2015). She was an excellent Spanish limnologist and dear friend.

\section{REFERENCES}

AGBENYEGA, O., P.J. BURGESS, M. COOK \& J. MORRIS. 2009. Application of an ecosystem function framework to perceptions of community woodlands. Land Use Policy, 26: 551-557. DOI: 10.1016/j.landusepol.2008.08.011

BALVANERA, P., S. QUIJAS, B. MARTÍN-LÓPEZ, E. BARRIOS, L. DEE, F. ISBELL, I. DURANCE, P. WHITE, R. BLANCHARD \& R. DE GROOT. 2015. The links between biodiversity and ecosystem services. In: Handbook of Ecosystems Services. M. Potchin, R. Haines-Young \& K. Turner (eds.): 45-61. Earthscan-Routledge.

BAN, N.C., E. BOYD, M. COX, C.L. MEEK, M. SCHOON \& S. VILLAMAYOR-TOMAS. 2015. Linking classroom learning and research to advance ideas about social-ecological resilience. Ecology and Society, 20(3): 35. DOI.org/10.5751/ES07517-200335

CARDINALE, B.J., J.E. DUFFY, A. GONZALEZ, D.U. HOOPER, C. PERRINGS, P. VENAIL, A. NARWANI, G.M. MACE, D. TILMAN, D.A. WARDLE, A.P. KINZIG, G.C. DAILY, M. LOREAU, J.B. GRACE, A. LARIGAUDERIE, D.S.
SRIVASTAVA \& S. NAEEM. 2012. Biodiversity loss and its impact on humanity. Nature, 486: 59-67. DOI:10.1038/nature11148

CASTRO, A.J., B. MARTÍN-LÓPEZ, M. GARCÍALLORENTE, P.A. AGUILERA, E. LÓPEZ \& J. CABELLO. 2011. Social preferences regarding the delivery of ecosystem services in a semiarid Mediterranean region. Journal of Arid Environments, 75: 1201-1208. DOI.org/10.1016/j.jaridenv. 2011.05.013

CASTRO, A.J., C.C. VAUGHN, J.P. JULIAN \& M. GARCÍA-LLORENTE. 2015. Social Demand for Ecosystem Services and Implications for Watershed Management. Journal of the American Water Resources Association (JAWRA): 1-13. DOI:10. 1111/1752-1688.12379

CHAN, K.M.A., M.R. SHAW, D.R. CAMERON, E.C. UNDERWOOD \& G.C. DAILY. 2006. Conservation Planning for Ecosystem Services. PLoS Biology, 4(11): e379. DOI:10.1371/journal.pbio.00 40379

CHAN, K.M.A., L. HOSHIZAKI \& B. KLINKENBERG. 2011. Ecosystem Services in Conservation Planning: Targeted Benefits vs. Co-Benefits or Costs? PLoS ONE. 6(9): e24378. DOI:10.1371/journal.po ne.0024378

CHAPIN III, F.S., S.R. CARPENTER, G.P. KOFINAS, C. FOLKE, N. ABEL, W.C. CLARK, P. OLSSON, D.M. STAFFORD SMITH, B. WALKER, O.R. YOUNG, F. BERKES, R. BIGGS, J.M. GROVE, R.L. NAYLOR, E. PINKERTON, W. STEFFEN \& F.J. SWANSON. 2010. Ecosystem stewardship: sustainability strategies for a rapidly changing planet. Trends in Ecology \& Evolution, 25: 241-249. DOI:10.1016/j.tree.2009.10.008

CLARK, W.C. \& N.M. DICKSON. 2003. Sustainability science: the emerging research program. Proceedings of the National Academy of Sciences of the United States of America, 100: 8059-8061. DOI:10.1073/pnas.1231333100

DE GROOT, R.S., M.A. WILSON \& R.M. J. BOUMANS. 2002. A typology for the classification, description and valuation of ecosystem functions, goods and services. Ecological Economics, 41(3): 393-408. DOI.org/10.1016/S0921-8009(02)0008 9-7

DELUCIO, J.V. \& M. MÚGICA. 1994. Landscape preferences and behaviour of visitors to Spanish national parks. Landscape and Urban Planning, 29: 145-160. DOI:10.1016/0169-2046(94)90024-8 
DÍAZ, S., J. FARGIONE, F. S. III. CHAPIN \& D. TILMAN. 2006. Biodiversity loss threatens human well-being. PLoS Biology, 4(8): 1300-1305. DOI:10.1371/journal.pbio.0040277

DÍAZ, A., F. QUÉTIER, D.M. CÁCERES, S.F. TRAINOR, N. PÉREZ-HARGUINDEGUY, M. SYNDONIA BRET-HARTE, B. FINEGAN, M. PEÑA-CLAROS \& L. POORTER. 2011. Linking functional diversity and social actor strategies in a framework for interdisciplinary analysis of nature's benefits to society. Proceeding of the $\mathrm{Na}$ tional Academy of Sciences, 108(3): 895-902. DOI:10.1073/pnas.1017993108

FISHER, B., R. K. TURNER \& P. MORLING. 2009. Defining and classifying ecosystem services for decision making. Ecological Economics, 68(3): 643653. DOI.org/10.1016/j.ecolecon.2008.09.014

GARCÍA-LLORENTE, M., B. MARTÍN-LÓPEZ, I. INIESTA-ARANDIA, C.A. LÓPEZ-SANTIAGO, P.A. AGUILERA \& C. MONTES. 2012. The role of multi-functionality in social preferences toward semi-arid rural landscapes: An ecosystem service approach. Environmental Science \& Policy, 19-20: 136-146. DOI.org/10.1016/j.envsci.2012.01.006

GARCÍA-LLORENTE, M., I. INIESTA-ARANDIA, B.A. WILLAARTS, P. A. HARRISON, P. BERRY, M. DEL MAR BAYO, A.J. CASTRO, C. MONTES \& B. MARTÍN-LÓPEZ. 2015. Biophysical and sociocultural factors underlying spatial tradeoffs of ecosystem services in semiarid watersheds. Ecology and Society, 20(3): 39. DOI.org/10.5751/ ES-07785-200339

HARRISON, P.A., M. VANDEWALLE, M.T. SYKES, P. M. BERRY, R. BUGTER, F. DE BELLO, C.K. FELD, U. GRANDIN, R. HARRINGTON, J.R. HASLETT, R.H. G. JONGMAN, G.W. LUCK, P. DA MARTINS SILVA, M. MOORA, J. SETTELE, J.P. SOUSA \& M. ZOBEL. 2010. Identifying and prioritising services in European terrestrial and freshwater ecosystems. Biodiversity and Conservation, 19: 2791-2821. DOI:10.1007/s10531010-9789-х

HARTTER, J. 2010. Resource use and ecosystem services in a forest park landscape. Society \& $\mathrm{Na}$ tural Resources: An International Journal, 23(3): 207-223. DOI.org/10.1080/08941920903360372

HOWE, C., H. SUICH, B. VIRA \& G.M. MACE. 2014. Creating winwins from trade-offs? Ecosystem services for human well-being: a meta-analysis of ecosystem service trade-offs and synergies in the real world. Global Environmental Change,
28: 263-275. DOI.org/10.1016/j.gloenvcha.2014. 07.005

INIESTA-ARANDIA, I., C. PIÑERO, C. MONTES \& B. MARTÍN-LÓPEZ. 2014. Women and agroecosystems conservation: an experiential analysis in the río Nacimiento region of Almería (Spain). Psychology: Bilingual Journal of Environmental Psychology, 5: 214-251.

KELEMEN,E., M. POTSCHIN, B. MARTÍN-LÓPEZ \& G. PATAKI. 2015. Ecosystem services: A gender perspective. In: OpenNESS Ecosystem Service Reference Book. M. Potschin \& K. Jax (eds.). EC FP7 Grant Agreement no. 308428. Available via: www.openness-project.eu/library/reference-book

LAMARQUE, P., F. QUÉTIER \& S. LAVOREL. 2011. The diversity of the ecosystem services concept and its implications for their assessment and management Comptes Rendus Biologies, 334(5): 441-449. DOI:10.1016/j.crvi.2010.11.007

LIU, J., H. MOONEY, V. HULL, S.J. DAVIS, J. GASKELL, T. HERTEL, J. LUBCHENCO, K.C. SETO, P. GLEICK, C. KREMEN \& S. LI. 2015. Systems integration for global sustainability. Science, 347: 1258832. DOI:10.1126/science.1258832 LÓPEZ-SANTIAGO, C.A., E. OTEROS-ROZAS, B. MARTÍN-LÓPEZ, T. PLIENINGER, E. GONZÁLEZ MARTÍN \& J.A. GONZÁLEZ. 2014. Using visual stimuli to explore the social perceptions of ecosystem services in cultural landscapes: the case of transhumance in Mediterranean Spain. Ecology and Society, 19(2): 27. http://dx.doi.org/10. 5751/ES-06401-190227

MA (Millennium EcosystemAssessment). 2005. Ecosystems and human well-being: synthesis. Island Press. Washington, DC.

MACE, G.M., K. NORRIS \& A. H. FITTER. 2012. Biodiversity and ecosystem services: a multilayered relationship. Trends in Ecology \& Evolution, 27(1): 19-26. DOI.org/10.1016/j.tree.2011.08.006 MARTÍN-LÓPEZ,B., E. GÓMEZ-BAGGETHUN, J.A. GONZÁLEZ, P.L. LOMAS \& C. MONTES. 2009. The assessment of ecosystem services provided by biodiversity: re-thinking concepts and research needs. In: Handbook of Nature Conservation: Global, Environmental and Economic Issues. J.B. Aronoff (ed.): 1-22. Nova Science Publishers. New York.

MARTÍN-LÓPEZ, B., I. INIESTA-ARANDIA, M. GARCÍA-LLORENTE, I. PALOMO, I. CASADOARZUAGA, D. GARCÍA DEL AMO, E. GÓMEZBAGGETHUN, E. OTEROS-ROZAS, I. PALA- 
CIOS-AGUNDEZ, B. WILLAARTS, J.A. GONZÁLEZ, F. SANTOS-MARTÍN, M. ONAINDIA, C. LÓPEZ-SANTIAGO \& C. MONTES. 2012. Uncovering Ecosystem Service Bundles through Social Preferences. PLoS ONE, 7(6): e38970. DOI:10.1371/journal.pone.0038970

MARTÍN-LÓPEZ, B., J.A. GONZÁLEZ, S.P. VILARDY, C. MONTES, M. GARCÍA-LLORENTE, I. PALOMO \& M. AGUADO. 2013. Ciencias de la Sostenibilidad: Guía Docente. Instituto Humboldt, Universidad del Magdalena, Universidad Autónoma de Madrid. Bogotá, Madrid.

OSTROM,E. 2009. A general framework for analyzing sustainability of social-ecological systems. Science, 325: 419-422. DOI:10.1126/science.1172 133

PÉREZ PICAZO, M.T. 2006. De campesino a ciudadano. La difícil penetración de la ciudadanía activa en la sociedad murciana. In: El otro estado de la Región. Informe 2006. Diego Marín/Foro Ciudadano de la Región de Murcia (eds.): 19-32. Murcia (Spain).

PETERSON, M.J., D.M. HALL, A.M. FELDPAUSCHPARKER \& T.R. PETERSON. 2010. Obscuring ecosystem function with application of the ecosystem services concept. Conservation Biology, 24(1): 113-119. DOI:10.1111/j.1523-1739. 2009.01305.x
PUIGDEFABREGAS, J. 2012. Los ecosistemas de la zona árida. Ambienta, 98: 154-183.

QUIJAS, S., L.E. JACKSON, M. MAASS, B. SCHMID, D. RAFFAELLI. \& P. BALVANERA. 2012. Plant diversity and generation of ecosystem services at the landscape scale: expert knowledge assessment. Journal of Applied Ecology, 49(4): 929-940. DOI:10.1111/j.1365-2664.2012.02153.x

RAUDSEPP-HEARNE, C., G.D. PETERSON \& E.M. BENNETT. 2010. Ecosystem service bundles for analyzing tradeoffs in diverse landscapes. Proceedings of the National Academy of Sciences of the United States of America, 107(11): 5242-5247. DOI:10.1073/pnas.0907284107

SNEA (Spanish National Ecosystem Assessment). 2014. Ecosystems and biodiversity for human wellbeing. Synthesis of the key findings. Biodiversity Foundation of the Spanish Ministry of Agriculture, Food and Environment (eds.). Madrid, Spain.

SOY-MASSONI, E., J. LANGEMEYER, D. VARGA, M. SÁEZ \& J. PINTÓ. 2016. The importance of ecosystem services in coastal agricultural landscapes: Case study from the Costa Brava, Catalonia. Ecosystem Services, 17: 43-52. DOI.org/10. 1016/j.ecoser.2015.11.004

UK NEA. 2011. The UK National Ecosystem Assessment Technical Report. UNEP-WCMC. Cambridge.

Con la colaboración de:

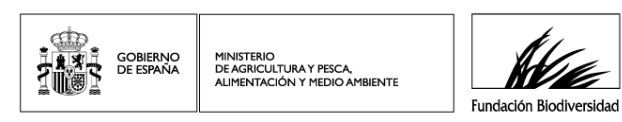

Limnetica, 36 (2): 479-490 (2017) 